\title{
Hermeneutics of Experimental Science in the Context of the Life-World
}

Patrick A. Heelan

Georgetown University, heelanp@georgetown.edu

Follow this and additional works at: https://fordham.bepress.com/phil_research

Part of the Continental Philosophy Commons, and the Philosophy of Science Commons

\section{Recommended Citation}

Heelan, Patrick A., "Hermeneutics of Experimental Science in the Context of the Life-World" (1974). Research Resources. 5. https://fordham.bepress.com/phil_research/5

This Article is brought to you for free and open access by the Hermeneutic and Phenomenological Philosophies of Science at DigitalResearch@Fordham. It has been accepted for inclusion in Research Resources by an authorized administrator of DigitalResearch@Fordham. For more information, please contact considine@fordham.edu. 


\title{
DISKUSSION
}

\section{Hermeneutics of Experimental Science in the Context of the Life-World*}

\author{
PATRICK A. HEELAN
}

I distinguished science as an element of our total contemporary culture, "historical science", from science as the professional business of natural scientists , "experimental science". Phenomenology has always taken a very critical stance against certain defects or biasses - objectivism, scientism, techicism - it has found in historical science. It is my purpose to show that these defects and biasses, associated historically with physical science, are not necessary parts of physical science, and consequently, that physics, especially experimental physics, has all of those hermeneutical, ontological, historical and dialectical dimensions negated by historical science. The notion of dialectic is given a formal logical construction as a time-dependent $Q$-lattice (Quantum-lattice or Quantum-logic), the form of which is suggested by quantum mechanics. The following positions are then proposed and defended: (1) Scientific states of affairs are given in an originary way to the experiencing scientist during the course of scientific observation. (2) Scientific observation involves a special non-objective use of the instrument; one in which the noetic intention is embodied in the instrument joined, physically and intentionally, with the scientist; this non-objective use is characterized by a hermeneutical shift in the subject-object cut so as to place the instrument on the subject side of the cut, and the instrumental signals in a position of a "text" to be "read" in a "context." (3) Scientific experimentation in the fullest sense involves the possibility of a human subject embodying himself in instrumentation not only for the purposes of observation, but also to create that context, physical and noetic, which is the condition of possibility for the scientific object to manifest itself in observation. (4) The historical fact of scientific revolutions confirms the hermeneutical aspect of experimental science and adds a dialectical movement to its history. (5) In consequence of what has been said, we can outline the moments in the genetic constitution of scientific objects as elements of the lifeworld of the scientist; the scientist first learns the objective use of instrumentation, then, through acquired expertise, he passes to a non-objective use of instrumentation characterized by the following: intentional or subjective

* Der hier abgedruckte Text ist der letzte Abschnitt der unter o. a. Titel in der Zeitschrift Philosophia Mathematica 9(1972), S. 101-144, erschienenen Untersuchung des Verfassers. Er soll als Zusammenfassung der dort erarbeiteten Resultate in die folgende Diskussion, die auf der Jahrestagung der Society for Phenomenology and Existential Philosophy in der Duquesne University in Pittsburgh, Pennsylvania. (USA) am 25. Oktober 1972 stattfand, einführen. Wir danken dem Herausgeber der Philosophia Mathematica, Herrn Prof. Dr. J. Fang, für die frdl. Genehmigung zum Wiederabdruck der Passage. - Die Herausgeber 
embodiment in instrumental artifacts, a hermeneutical shift in the subjectobject cut, and the assimilation of instrumental signals to a text. (6) Technological artifacts make possible modes of observational givenness which, unlike experimental science, are constituted by human technical interests; within this context scientific terms are used with analogical meanings. (7) Quantum mechanics as a physical science gives a logical model, the $Q$-lattice, for the relation between context-dependent and dialectically related languages, that is, languages supposing relatively non-compossible modes of subjectitiy. (8) Quantum mechanics cannot be understood without recourse to a transcendental language that is the dialectical synthesis, in a $Q$-lattice, of physics and psychology. (9) The hermeneutic aspects of natural scince and technology have momentous consequences for the evolution of human subjectivity and the lifeworld.

Adresse des Autors:

Prof. Dr. Patrick A. Heelan, Department of Philosophy, State University of New York, Stony Brook, N.Y., 11790, USA

\section{Commentary on Patrick Heelan's "Hermeneutics of Experimental Science in the Context of the Life-World"}

THEODORE KISIEL

The topic for this session, when isolated and typed, is in fact a rare species of a rather common genus, namely, the phenomenology of natural science. Moreover, the paper before us identifies an even rarer subspecies, the hermeneutics of natural science, which in most quarters would certainly be viewed as a monstrous hybrid. For ever since the days of Schleiermacher and Dilthey, hermeneutics has become the method distinct to the human sciences and distinguished sharply from the method employed by the natural sciences.

It is in fact surprising how this species of phenomenology even today is seldom pursued. Aside from Professor Heelan's unique and most welcome contributions in this direction, one might recall Joseph Kockelman's work along Heideggerian lines and look forward to the forthcoming book promised by Aron Gurwitsch in the tradition of Husserl. And yet, in view of the latest developments in the philosophy of science, it seems that the time is ripe for phenomenologists to take advantage of decades of incubation and programmatic maneuvering by applying the categories thus developed to some of the issues raised by the new philosophy of science.

After a promising start by Hermann Weyl, Oskar Becker, Hedwig Conrad-Martius, Moritz Geiger and others, the application of phenomenological categories to the more specific philosophical issues of natural science lapsed into a state of neglect by the second generation of phenomenologists. Aside from contingent historical factors, one major reason 